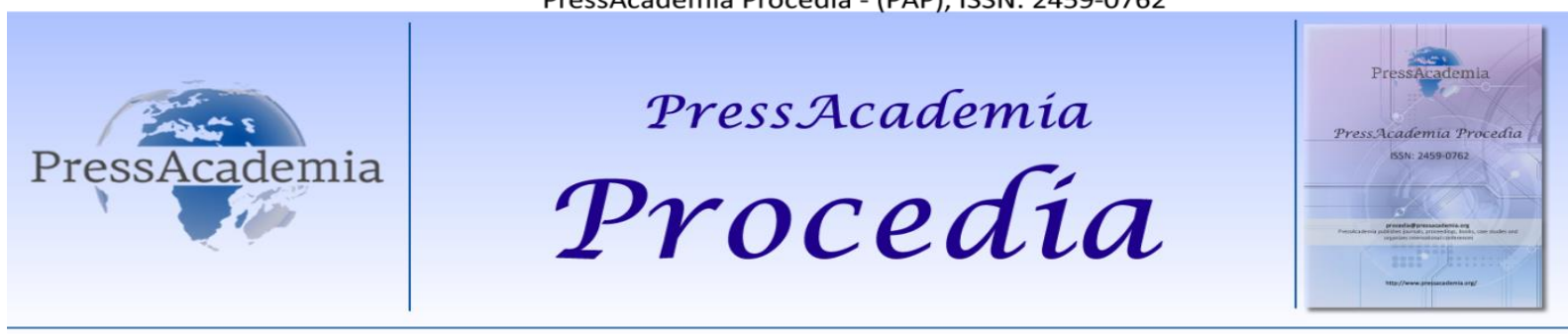

Global Business Research Congress (GBRC), May 24-25, 2017, Istanbul, Turkey.

\title{
SOCIAL MEDIA AND INVESTMENT FIRMS IN TURKEY
}

\author{
DOI: 10.17261/Pressacademia.2017.418
}

PAP-GBRC-V.3-2017(33)-p.337-349

Lale Aslan

Istanbul Yeni Yuzyil University, Ayazma Caddesi, No: 26 P.K. 34010 Cevizlibag, Zeytinburnu, Istanbul, Turkey. Iale.aslan@yeniyuzyil.edu.tr

To cite this document

Aslan, L.. (2017). Social media and investment firms in Turkey. PressAcademia Procedia (PAP), V.3, p.337-349

Permanent link to this document: http://doi.org/10.17261/Pressacademia.2017.418

Copyright: Published by PressAcademia and limited licenced re-use rights only.

\begin{abstract}
Social media has become an important aspect of finance in the past few years and all reputable firms like to present themselves in social media, because it implies a corporate identity from the investors' point of view. Especially for generation $Y$ and millennials who are born to the age of internet, social media has become a way of life. It is also the key of life for corporations that want to reach these generations as a part of their client portfolio. The aim of this paper is to investigate the social media presence of Turkish intermediary institutions and figure out whether these institutions have managed to make an online impression and whether this impression has taken an effect on the financial front for these firms by analyzing related income and other related indicators such as client complaints as well as taking into account the strategies involving Istanbul Financial Center Project (IFC). Data belonging to a total of 66 intermediary institutions are collected and independent t-test and parametric and nonparametric correlations analyses are applied to data. According to analysis results there is a significant relationship between social media presence of intermediary institutions and authorization certificate types of these institutions, forex income and the number of client complaints. Location of intermediary institutions is found not to be significant, opposite of suggested by IFC. Only half of Turkish intermediary institutions are found to be effectively present in social media. This unwillingness of intermediary institutions limits the promotion of finance sector and contradicts the IFC project.
\end{abstract}

Keywords: Intermediary Institutions, fnance, social media, income, corporations.

JEL Codes: G24, 016, M20

\section{INTRODUCTION}

Andy Warhol predicted that "in the future, everybody will be world-famous for fifteen minutes" (Anon., 2016). Social media has made it possible that indeed everyone has access to online platforms that can make them famous, or act as if famous in their social circle. While the impact of this phenomenon on the human psyche is reflected on psychology and sociology; today's global and intricate way of life makes sure that in order to reach generation $Y$ and millennials as potential customers, financial institutions are increasingly becoming part of this virtual world.

This paper investigates the social media presence of intermediary institutions established in Turkey. The advances in digital platforms affect how a business can be developed and flourished. Thus, social media has become a very important medium in promoting businesses. For intermediation sector, this is especially important because efficient markets can only exist in an environment where information flows freely and as quickly as possible (Malkiel, 2003, p. 59) and the quickest and free way of conveying information is through social media platforms such as Facebook, Twitter, and Youtube. 
Even though, social media is an important part of information feeds, not all intermediary institutions are interested in being present in these platforms and promoting their brands online via these platforms by being in continual touch with their clients. As very well explained in the literature, customer loyalty is increased when customers are engaged with a brand that promotes a certain lifestyle by forming lasting relationships (Nyadzayo and Khajehzadeh, 2016). In order to promote an investor based lifestyle engagement with $24 / 7$ operating markets all around the world, social media is the handiest tool for intermediary institutions.

The aim of this paper is to depict the lack of presence in social media platforms and how intermediary institutions that are present in social media differ from those that are not present. In order to achieve the results concerning this problem, necessary data of intermediary institutions are gathered from related government agency websites, intermediary institutions' websites and social media platforms and analyzed by using independent samples t-test and parametric and nonparametric correlation analyses.

\section{LITERATURE REVIEW}

Social media has become an irreplaceable aspect of everyday life and this situation has created its own culture by forming online communities and groups (Islam and Rahman, 2017). Under such conditions, firms are under pressure to represent themselves and form communities in social media platforms. Especially millennials make up a significant part of online shoppers (Bilgihan, 2016). In Turkey, also young population is found to be dominant in social media platforms. According to Hootsuite survey (2017), social media penetration (being active on social media accounts) is $60 \%$, which is quite over the world average and an average Turkish citizen spends 3 hours on social media each day. These numbers are paramount in showing any firm where to find clients.

Especially Facebook is an important platform for marketing purposes in Turkey since Turkey is the top $7^{\text {th }}$ country with $48,000,000$ users and $21 \%$ of these users are between ages 18 and $34(27,620,000$ people - which makes up approximately $35 \%$ of the total population) (Hootsuite, 2007). The numbers clearly show how important social media presence is if a company wants to reach young people or a significant part of the population and this consequence is repeated throughout the world (Correa, Hinsley and Gil de Zúñiga, 2010 and Hristova, Panzarasa and Mascolo, 2015).

The effectiveness of social media in creating a brand value is emphasized in various aspects such as "stimulating sales, increasing brand awareness, improving brand image, generating traffic to online platforms, reducing marketing costs, and creating user interactivity on platforms by stimulating users to post or share content"(Felix, Rauschnabel and Hinsch, 2017, p. 119).

Corporate reputation management can be most effectively carried out via social media platforms since it is quite easy to communicate with clients and help build a brand name. On the other hand lack of communication is evaluated as poor reputation management by clients (Altunbas and Diker, 2015).

There are 3 ways to use social media for intermediary institutions. Firstly, a social media account can be used to publicize the company in order to reach a wider mass of potential clients. Secondly, social media can be used to educate people who do not have financial literacy on financial markets and products. This is generally considered as middle - term investment; once a potential client is educated on investing, $\mathrm{s} /$ he might actually consider investing in capital markets via the institution s/he received education and notwithstanding considerable attention from. Once the client starts investing, the intermediary institution can install the third way of usage of social media: conveying timely and accurate information on markets and related developments that will provide market efficiency for the client.

Once the third stage is active, the company has to maintain the relationship by consistent posting; it is vital to keep the bond between client and the firm strong. "The higher the social presence, the larger the social influence that the communication partners have on each other's behavior" (Kaplan and Haenlein, 2010, p. 61).

With such impact on business, social media "brings a new point of view to existing jobs"(Uzgören and Korkmaz, 2015), thus businesses that are not involved in social media fall behind in competition as well as innovation in marketing. One of the major benefits of social media is that it allows small cap firms to compete with large cap firms; in a sense, all firms have equal chances of reaching customers (Halis, 2012). Thus, it is possible to suggest that an effective social media presence will show its impact on income generating abilities of the firm. In this context, one of the problems to be investigated in this paper is the association of social media presence of intermediary institutions and forex operations income. Since it is mandatory for clients to have an online presence to be able to open an account to perform forex operations according to Capital Markets Board of Turkey (CMB) Communiqué no. III-37.1 on "Principles Regarding Investment Services, Activities and Ancillary Services" article 27/C. The same prerequisite is not necessary for performing other transactions such as buying/selling shares, derivatives, funds, etc. Thus, it is possible to follow the association between social media presence and forex income of intermediary institutions. 
In addition to this, intermediary institutions that have a wider choice of products, and that have substantially high capital, have more personnel to contribute to social media accounts. The need of marketing is higher for these firms because of their product mix. Also, firms that have higher capital amounts are likely to be located in traditional business venues, and such firms are expected to have a significant presence in social media.

Another problem to be depicted with this paper is the association of client complaints with social media presence. Since clients form communities on social media platforms, they have more power over firms. Increased means of communication helps clients to reach investment firms and get quicker responses to their complaints.

\section{DATA AND METHODOLOGY}

\subsection{Sample and Procedure}

In order to determine the aspects of the Investment Firms that are present in social media platforms, correlations and independent samples t-test analyses are conducted.

The analyses are conducted on the whole population of active ${ }^{1}$ investment firms ${ }^{2}$ in Turkey. As of April 30, 2017, there are 84 intermediary institutions established in Turkey, however, due to various reasons, there are only 68 actively operating intermediary institutions according to Turkish Capital Markets Association. According to research results, only $66^{3}$ of these institutions are active as of April 1, 2017. Thus only these active 66 institutions make up the population. Since inactive intermediary institutions are not engaged any kind of brokerage activities or operating activities, they are excluded from the analyses.

There are five variables that are included in the analyses and these are explained in detail in the next section.

\subsection{Variables}

\subsubsection{Social Media Presence}

Social media presence shows whether an investment firm has any social media accounts and it is the dependent variable in this paper. According to a recent survey done by Hootesuite (2017) called "Digital in 2017 Global Overview: A Collection of Internet, Social Media, and Mobile Data from Around the World" the most popular social media platforms in Turkey are depicted in Graph 1 below. According to the graph, the most popular social media platform is Youtube with $57 \%$ preference of users. Facebook comes in second with $56 \%$ user preference. Instagram is third with $45 \%$ and Twitter is in fourth place with $44 \%$ user preference.

Graph 1: Most Active Social Media Platforms in 2017 in Turkey

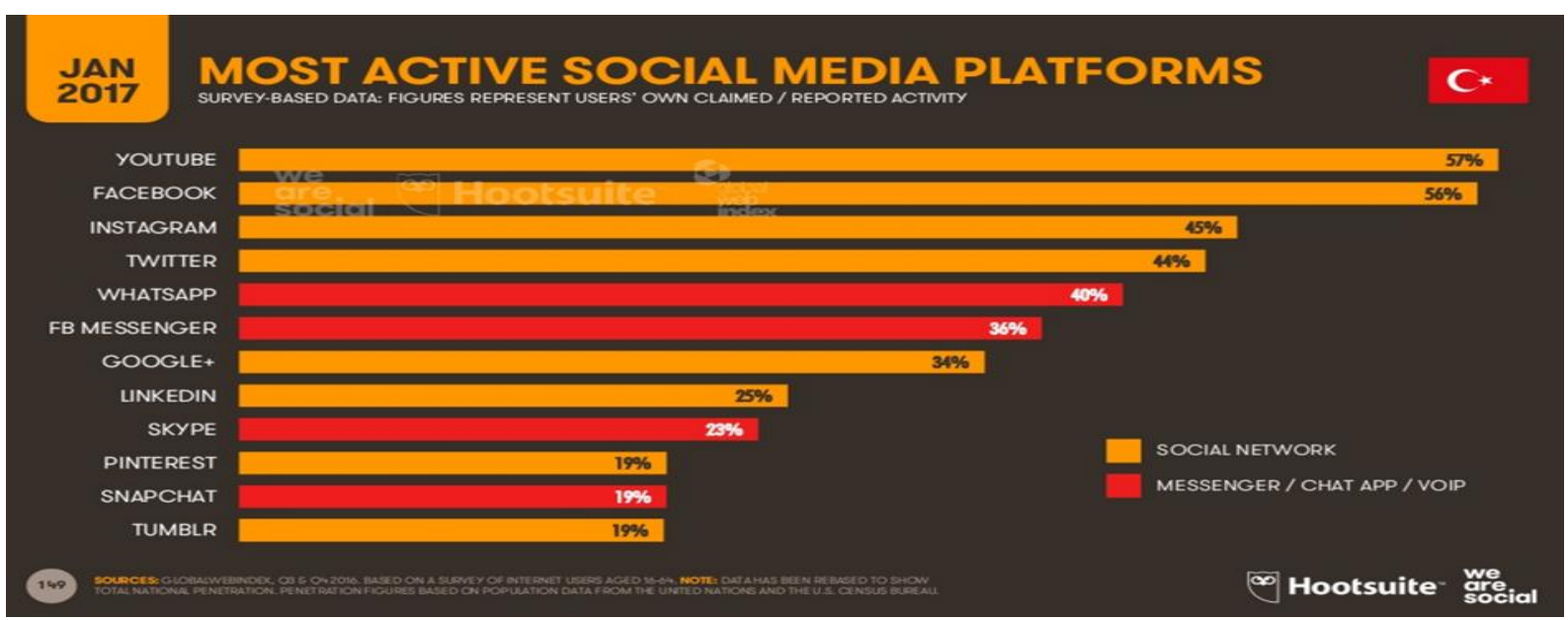

Source: https://www.slideshare.net/wearesocialsg/digital-in-2017-global-overview

\footnotetext{
${ }^{1}$ Temporary discontinuation of activities is allowed by Capital Markets Board of Turkey. The list of intermediary institutions may be reached via https://www.tspb.org.tr/en/members/ [accessed on April 28, 2017]

2 'Investment firms' expression is used interchangeably with 'intermediary institutions' expression both of which mean brokerage firms.

${ }^{3}$ This difference is caused by two institutions. 1) Ekspres Yatirim Menkul Degerler A.S. is allowed temporary discontinuation of its activities as of March 20, 2017. 2) Galata Menkul Degerler A.S. does not have a website although this is mandatory according to Communiqué no. III-39.1 on Principles of Establishment and Activities of Investment Firms, Article 28. The company has only a Linkedin account that does not have any posts and it is not possible to reach the firm by telephone, thus it is excluded from the research.
} 
Being a member in the most popular social media platforms increase the institutions' recognition by masses that are using these platforms. The more popular the social media platform, the greater the chance to increase potential clients.

As can be seen from the graph above, social media platforms can be divided into 2 groups: i. Social networks and ii. Messenger and chat applications. However, it is not possible to always find out which messenger or chat applications an intermediary institution is using, thus they are excluded from the analyses. Furthermore, according to Communiqué no. III45.1 Article 8 called "Documentation and Recording Regulation Regarding Investment Services and Activities and Ancillary Services" published Capital Markets Board of Turkey (CMB); all client orders received in the electronic environment have to be logged to show various details on order including IP numbers. It is deemed not possible to take orders from such messenger and chat applications under this regulation.

The social media platforms included in the analyses are; Youtube, Facebook, Instagram, Twitter, Google+ and Linkedin. To find out which social media platforms are used by intermediary institutions, the links present in the institutions' websites were tracked. Also, the author used her personal social media accounts to double check the existence of such links.

The presence of an investment firm is marked as 1 and lack of presence is represented by 0 in the coding of data. Also, timeline of social media posts are investigated and firms that have recurring entries within 1 week are evaluated as very effective users and coded as 3 . Firms that have opened accounts, but never posted any entries are evaluated not effective and coded as 1 . Firms that are between these two, meaning firms that post occasionally are evaluated as semi-effective and coded as 2 . Firms that do not own any accounts are coded as 0.

\subsubsection{Authorization Certificates}

According to Article 8 of CMB Communiqué no. III-37.1 on "Principles Regarding Investment Services, Activities and Ancillary Services", intermediary institutions are grouped into three categories:

i. Narrowly Authorized Intermediary Institutions

ii. Partially Authorized Intermediary Institutions

iii. Broadly Authorized Intermediary Institutions

The content of authorization each level provides for intermediary institutions is given in Table 1 below.

Table 1: Groups of Intermediary Institutions and List of Activites They Are Allowed to Perform

\begin{tabular}{|lccc|} 
Intermediary Institution & $\begin{array}{c}\text { Order Reception and } \\
\text { Investment Advice }\end{array}$ & $\begin{array}{c}\text { Order Execution, Best } \\
\text { Effort, Limited Custody } \\
\text { \& Portfolio Management }\end{array}$ & $\begin{array}{c}\text { Proprietary Trading, } \\
\text { General Custody, } \\
\text { Underwriting }\end{array}$ \\
\hline Narrowly Authorized & $\checkmark$ & $\mathrm{X}$ & $\mathrm{X}$ \\
\hline Partially Authorized & $\checkmark$ & $\checkmark$ & $\mathrm{X}$ \\
\hline Broadly Authorized & $\checkmark$ & $\checkmark$ & $\checkmark$ \\
\hline
\end{tabular}

Narrowly authorized intermediary institutions are coded as 1, partially authorized intermediary institutions are coded as 2 , and broadly authorized intermediary institutions are coded as 3.

\subsubsection{Location}

According to Istanbul Financial Center Project, Istanbul is to become a financial hub for the Middle East and Balkans region (http://www.istanbulfinansmerkezi.com/). Atasehir district is in the heart of this project. Following this thought, whether the actual location of an investment firm has any association with its presence in social media is investigated.

The business districts are scattered throughout Istanbul without much planning involved and whether a firm's location being a business district has an association with how the firm likes to present itself is an important point to consider.

For this study, investment firm locations are grouped and coded into 2 categories as follows:

1. 4. Levent, Levent, Maslak, Esentepe, Mecidiyekoy \& Sisli: The business district where the majority of financial institutions are based.

2. Other Districts: This group includes Bağcılar, Batı Ataşehir, Bayrampaşa, Beşiktaş, Beyoğlu, Çağlayan, Dikilitaş, Elmadağ, Etiler, Gümüşsuyu, Kadıköy, Kağıthane, Kartal, Kavacık, Sarıyer, Taksim, Teşvikiye, Ümraniye, and Yenisahra; 1 or 2 firms located in each district. 


\subsubsection{Forex Income}

Forex transactions cannot be made on paper, thus all clients who want to engage in such transactions have to have e-mail addresses and mobile phones, to be able to use internet based platforms where these transactions take place. Thus, clients that are more active on the internet are expected to have social media accounts and intermediary institutions can increase their forex income by targeting such clientele. Forex income for the period ending December 2016 is announced by Turkish Capital Markets Association's website (https://www.tspb.org.tr/en/data-bank/).

\subsubsection{Number of Client Complaints}

Social media has made it easier to reach firms and as a result client complaints are addressed quicker when they are posted online. In addition to this, if the complaining client has many followers, this leaves the firm with a bad reputation. This is why client complaints are expected to be high for investment firms that have social media accounts. Client complaints are also announced by Turkish Capital Markets Association's website.

\subsubsection{Hypotheses}

Hypothesis 1: Authorization certificates of institutions that have social media presence are significantly different from institutions that do not have social media presence.

Hypothesis 2: Locations of institutions that have social media presence are significantly different from institutions that do not have social media presence.

Hypothesis 3: Forex incomes of institutions that have social media presence are significantly different from institutions that do not have social media presence.

Hypothesis 4: Number of client complaints of institutions that have social media presence is significantly different from institutions that do not have social media presence.

\section{FINDINGS AND DISCUSSIONS}

\subsection{Descriptives}

Of the 66 active intermediary institutions, 22 (33\%) of them are not present in any kind of social media platform. The remaining $2 / 3$ are present in at least one social media platform. According to Table 2, which categorizes intermediary institutions first by social media participation, then type of authorization certificate; only 10 nonparticipant institutions are able to generate forex income of 38.243 .576 є. On the other hand, institutions that have some kind of social media presence are able to generate a total of 371.078 .612 ₹ of Forex income, which in turn makes up $91 \%$ of total forex income in the sector as depicted in Graph 2.

In both firm types (nonparticipant and participant), client complaints are higher in broadly authorized institutions; although there is a substantial difference between complaint numbers as can be seen from Table 2 when compared. The number of client complaints is significantly low in nonparticipant institutions when compared to participant institutions due to participant institutions' presence in social media makes it easier for clients to make their voice heard.

Table 2: Investment Institutions and Participation in Social Media

\begin{tabular}{|c|c|c|c|}
\hline \multicolumn{4}{|c|}{ Investment Institutions } \\
\hline $\begin{array}{l}\text { Nonparticipant in Social } \\
\text { Media }\end{array}$ & 22 & & \\
\hline $\begin{array}{l}\text { Type of Authorization } \\
\text { Certificate }\end{array}$ & $\begin{array}{l}\text { Number of } \\
\text { Institutions Allocated } \\
\text { According to } \\
\text { Authorization } \\
\text { Certificate }\end{array}$ & Forex Income & Number of Complaints \\
\hline 1 & 2 & 0 & $\mathrm{O}$ \\
\hline 2 & 10 & 0 & 0 \\
\hline 3 & 10 & 38.243.576も & 10 \\
\hline Participant in Social Media & 44 & & \\
\hline $\begin{array}{l}\text { Type of Authorization } \\
\text { Certificate }\end{array}$ & $\begin{array}{l}\text { Number of } \\
\text { Institutions Allocated } \\
\text { According to } \\
\text { Authorization } \\
\text { Certificate } \\
\end{array}$ & Forex Income & Number of Complaints \\
\hline 1 & 0 & 0 & 0 \\
\hline 2 & 2 & $1.836 .527 も$ & 3 \\
\hline 3 & 42 & 369.242.085も & 143 \\
\hline
\end{tabular}




\title{
Distribution of Forex Income
}

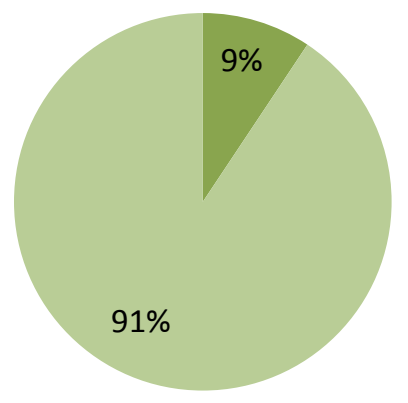

\author{
Nonparticipant \\ Institutions \\ Participant Institutions
}

\section{Table 3: Social Media Presence vs. Location}

\begin{tabular}{|c|c|c|c|c|c|}
\hline \multicolumn{6}{|c|}{ INVESTMENT INSTITUTIONS } \\
\hline Participant in Social Media & Location & Authorization Certificate & Number of Institutions & Forex Income & Number of Complaints \\
\hline \multirow{6}{*}{ NO } & \multirow{3}{*}{1} & 1 & 1 & 0 0屯 & 0 \\
\hline & & 2 & 5 & 0 聿 & 0 \\
\hline & & 3 & 6 & 10.541.164も & 1 \\
\hline & \multirow{3}{*}{2} & 1 & 1 & 0 0 & 0 \\
\hline & & 2 & 5 & 0 0 & 0 \\
\hline & & 3 & 4 & $27.702 .412 も$ & 9 \\
\hline \multirow{6}{*}{ YES } & \multirow{3}{*}{1} & 1 & 0 & $\mathrm{~N} / \mathrm{A}$ & N/A \\
\hline & & 2 & 2 & 1.836.527も & 3 \\
\hline & & 3 & 28 & 313.667 .326 も & 100 \\
\hline & \multirow{3}{*}{2} & 1 & 0 & N/A & N/A \\
\hline & & 2 & 0 & N/A & N/A \\
\hline & & 3 & 14 & 55.574 .759 も & 43 \\
\hline
\end{tabular}

The majority of forex income is generated due to the intermediary institutions' social media presence making an impact on existing clientele. When effects of location are taken into account, it is possible to see that majority of forex income is generated by companies located in best-known business districts, according to Table 3. Companies located in Location 1 generate 326,045,017も Forex income, which equals 75\% of total Forex income; while companies located in Location 2 generate $83,277,171$ є Forex income equal to $25 \%$ as can be seen from Table 3 . However, the majority of client complaints are caused by the firms located in Location 1 as well (104 vs. 52 client complaints).

The following chart gives the breakdown of social media platforms that intermediary institutions are active on. Intermediary institutions are mostly active on Twitter (31\%) and Youtube (28\%) as stated in Graph 3. These results are somewhat compliant with the Hootsuite survey results presented in Part 3. For instance, according to Hootsuite survey, Facebook is the second most popular social media platform in Turkey, however, only $20 \%$ of intermediary institutions have joined facebook. Also, Instagram is the third most popular social media platform with $45 \%$ preference, but only $6 \%$ of intermediary institutions have opened accounts on Instagram. 


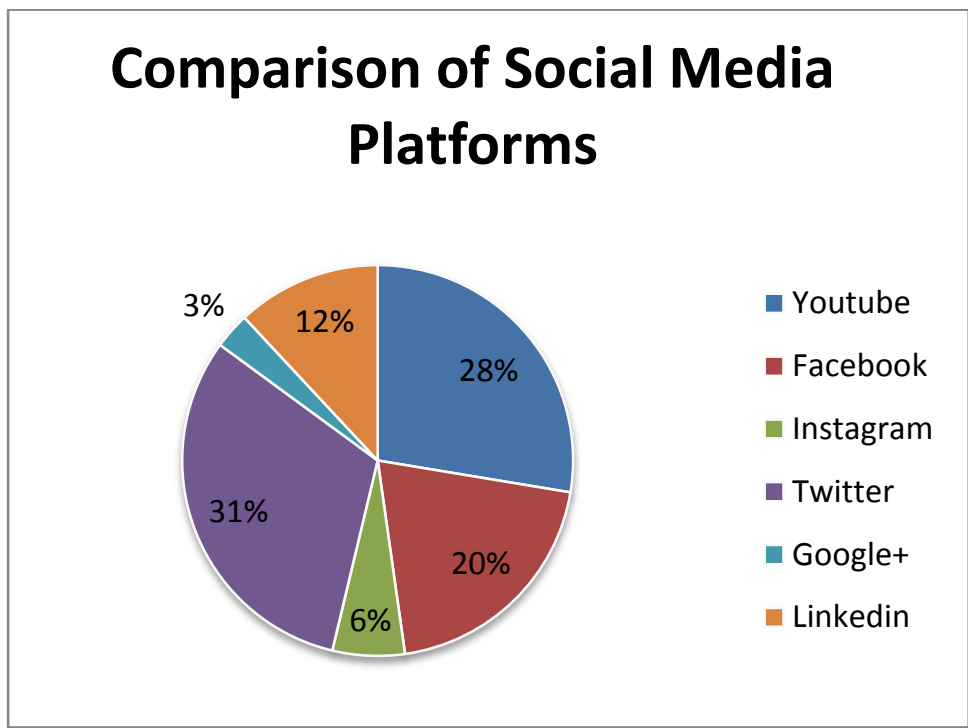

\begin{tabular}{|c|c|}
\hline $\begin{array}{c}\text { Social Media } \\
\text { Platform }\end{array}$ & $\begin{array}{c}\text { Number of } \\
\text { Institutions }\end{array}$ \\
\hline Twitter & 42 \\
\hline Youtube & 37 \\
\hline Facebook & 27 \\
\hline Linkedin & 16 \\
\hline Instagram & 8 \\
\hline Google+ & 4 \\
\hline
\end{tabular}

According to descriptive statistics results, data are found to be nonnormal. Mean of 'Social Media Presence' is equal to 0.66 which states that only $2 / 3$ of intermediary institutions are actively engaged in social media. Its standard deviation is equal to 0.47 , has medium negative skewness and a platykurtic distribution.

'Authorization Certificate Type' data are found to be nonnormal and mean value is equal to 2.75 with a standard deviation of 0.49 , meaning that majority of intermediary institutions are broadly authorized. Breakdown of intermediary institutions according to their authorization type is given below in Graph 4. Data have highly negatively skewed and excessively leptokurtic distribution.

Graph 4: Breakdown of Intermediary Institutions According to Authorization Levels

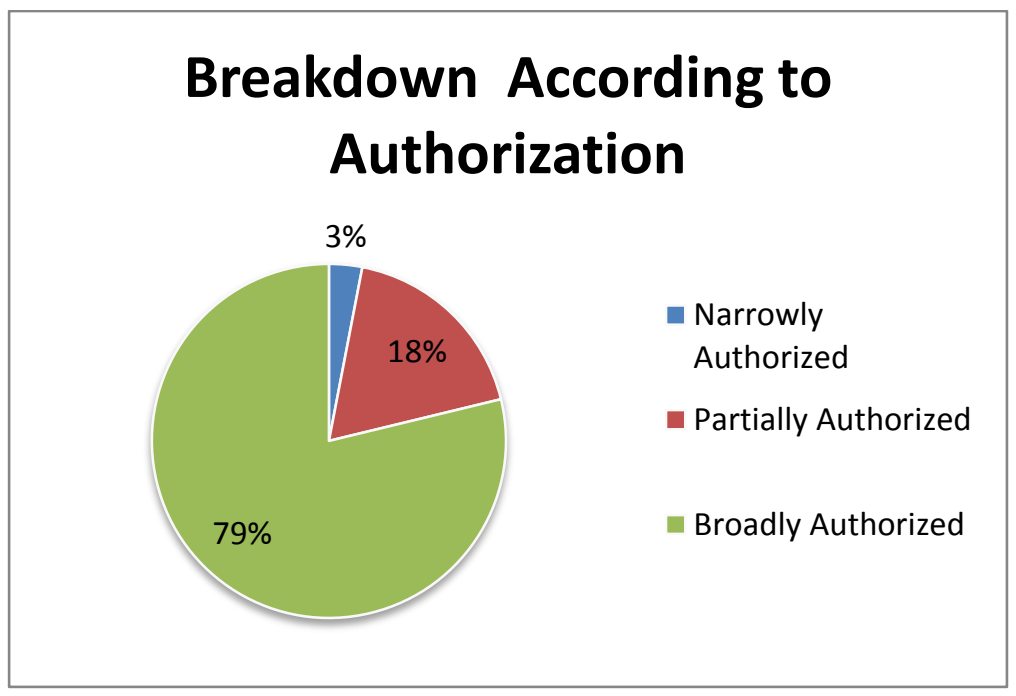

\begin{tabular}{|c|c|}
\hline $\begin{array}{c}\text { Authorization } \\
\text { Certificate Type }\end{array}$ & $\begin{array}{c}\text { Number of } \\
\text { Institutions }\end{array}$ \\
\hline $\begin{array}{c}\text { Narrowly } \\
\text { Authorized }\end{array}$ & 2 \\
\hline $\begin{array}{c}\text { Partially } \\
\text { Authorized }\end{array}$ & 12 \\
\hline $\begin{array}{c}\text { Broadly } \\
\text { Authorized }\end{array}$ & 52 \\
\hline
\end{tabular}

'Location of the Firm' data show that the majority of intermediary institutions are located in traditional financial business districts (4 Levent, Levent, Maslak, Esentepe, Mecidiyekoy, and Sisli) with a mean of 1.36 and a standard deviation of 0.48 . Data are moderately skewed and highly platykurtic.

'Income from Forex Operations' data state that average forex income per institution is equal to $6,201,851$ with a highly positively skewed and leptokurtic distribution. 
'Number of Client Complaints' data shows that there are at least 2 complaints per institution, which is not a critically high number. Data are highly positively skewed and have a leptokurtic distribution.

\subsection{T-test Results}

According to independent t-test results; authorization certificate type, forex income and number of client complaints are found to be significant. Thus, hypothesis 1,3 and 4 are not rejected. However, location is found to be insignificant, thus hypothesis 2 is rejected.

According to the analyses results, there is a significant difference between the authorization certificates of institutions present in social media platforms and those institutions that are not present in social media platforms. Broadly authorized institutions are found to be more active in this venue. This is also true for forex income. Investment institutions that are involved in social media are able to generate greater forex income. Moreover, number of complaints is found to be higher for firms that have social media accounts, because firms that are present in social media are preferred by clients because of increased market popularity. A higher number of client complaints point to a higher number of clients. Also, clients tend to prefer firms that can be reached easily and that provide them with a constant flow of information, which in turn increases market efficiency.

The majority of intermediary institutions are closely located; however social media presence does not have any association with location according to analyses results. Apparently, social media preferences of firms do not depend on their being able to afford expensive offices; instead, such decisions depend on the marketing strategy and management philosophy of intermediary institutions.

\subsection{Correlation Results}

Both parametric and nonparametric correlation analyses are applied to the data set. According to parametric correlation results, authorization certificate type is found to be significant at 0.01 level and forex income and number of client complaints are found to be significant at 0.05 level. 'Location' is not found to be significant. Nonparametric correlation results depict the same outcome, all three variables are found to be significant at 0.01 level. These findings confirm the $t-$ test results.

\section{CONCLUSION}

Today, it is impossible to deny the benefits of social media for firms and consumers alike. For firms, social media platforms provide free mass marketing for businesses that are willing to grow their client portfolio. On the other hand, social media helps people to come together and form communities. When these communities are directed towards firms, social media presence can make companies vulnerable in a way, because any complaints about the institutions' products and services are announced in a publicly open platform. Reputation management requires all complaints to be handled swiftly; therefore clients prefer to convey their complaints via social media platforms. This result indicates the importance of reputation management and how to handle social media accounts carefully for firms and especially intermediary institutions because the content of social media messages has to reflect the truth to ensure market efficiency. The finance sector is built on mutual trust and in order to preserve a solid relationship with clients, intermediary institutions have to be present in social media, educating and informing their clients about capital markets.

This paper tries to fill the gap concerning the lack of studies on Turkish finance sector. With the government putting emphasis on growth of finance sector and Istanbul being the focal point, it seems only a part of financial institutions are making an effort to fulfill this mission. This result is derived from the lack of social media presence of half the intermediary institutions in the sector, which is damaging the promotion of the sector, as well as their own financial outlook.

Even though management styles and CEOs of intermediary institutions are not covered in this paper due to limitations; it is not irrelevant to think that innovative management is what Turkish intermediary institutions are in need of. Also, a content analysis concerning social media accounts of intermediary institutions would provide priceless support to findings of this paper.

\section{REFERENCES}

Anon.(2016). Andy Warhol Biography. Available at: http://warholfoundation.org/legacy/biography.html [Accessed on March 10, 2017].

Altunbas, H. and Diker, E., (2015). Corporate reputation management and social media: An analysis on facebook accounts of the most valuable 5 brands in Turkey. Erciyes iletisim Dergisi “Academia”, vol. 4, no. 2, pp. $40-54$.

Bilgihan, A., (2016). Gen Y customer loyalty in online shopping: An integrated model of trust, user experience and branding. Computers in Human Behavior, vol. 61, pp. $103-113$. 
Capital Markets Board of Turkey, Communiqués no. III-37.1, III-39.1 and III-45.1 http://www.cmb.gov.tr/apps/teblig/ [Accessed on April 3, 2017].

Correa, T., Hinsley, A. W., and Gil de Zúñiga, H., (2010). Who interacts on the web? The intersection of users' personality and social media use, Computers in Human Behavior, vol. 26, pp. $247-253$.

Hootsuite., (2017). Digital in 2017 Global Overview: A Collection of Internet, Social Media, and Mobile Data from Around the World. https://www.slideshare.net/wearesocialsg/digital-in-2017-global-overview [accessed on April 3, 2017]

Hristova, D., Panzarasa, P. and Mascolo, C., (2015). Multilayer brokerage in geo - social networks. Available at: https://pdfs.semanticscholar.org/c31e/7ae20be4d46240386547afb38d49dcf8b6d6.pdf [Accessed on March 10, 2017].

Felix, R., Rauschnabel, P.A., and Hinsch, C., (2017). Elements of strategic social media marketing: A holistic framework. Journal of Business Research, vol. 70, pp. $118-126$.

Halis, B., (2012). The changing face of consumption: E - commerce applications and the role of social networks. Journal of History Culture and Art Research, vol. 1, no. 4, pp. $149-160$.

Islam, J.U., and Rahman, Z. (2017). The Impact of online brand community characteristics on customer engagement: An application of stimulus-organism-response paradigm. Telematics and Informatics, vol. 34, issue 4, pp. $96-109$.

Kaplan, A. M. and Haenlein, M., (2010). Users of the world, unite! The challenges and opportunities of social media.Business Horizons, vol. 53 , pp. $59-68$.

Malkiel, G.G., (2003). The efficient market hypothesis and its critics. Journal of Economic Perspectives, vol.17, no.1, pp. $59-82$.

Nyadzayo, M. W. and Khajehzadeh, S., (2016). The antecedents of customer loyalty: A moderated mediation model of customer relationship management quality and brand image. Journal of Retailing and Consumer Services, vol. 30, pp. 262 - 270.

Uzgoren, E. and Korkmaz, I., (2015). An examination on microeconomic foundations of social media economics. Optimum Journal of Economics and Management Sciences, vol. 2, no. 1, pp. $63-73$.

\section{Internet References}

Istanbul Finance Center website, http://www.istanbulfinansmerkezi.com/ [Accessed on March 10, 2017]

Turkish Capital Markets Association website, https://www.tspb.org.tr/en/data-bank/ [Accessed on April 3, 2017] 


\section{APPENDIX}

\begin{tabular}{|c|c|c|c|c|c|c|c|c|c|c|c|c|c|}
\hline \multicolumn{14}{|c|}{ Descriptive Statistics } \\
\hline & $\mathrm{N}$ & Range & Minimum & Maximum & Sum & \multicolumn{2}{|c|}{ Mean } & Std. Deviation & \multirow{2}{*}{$\begin{array}{l}\text { Variance } \\
\text { Statistic }\end{array}$} & \multicolumn{2}{|c|}{ Skewness } & \multicolumn{2}{|c|}{ Kurtosis } \\
\hline & Statistic & Statistic & Statistic & Statistic & Statistic & Statistic & Std. Error & Statistic & & Statistic & $\begin{array}{l}\text { Std. } \\
\text { Error }\end{array}$ & Statistic & $\begin{array}{l}\text { Std. } \\
\text { Error }\end{array}$ \\
\hline $\begin{array}{l}\text { Social Media } \\
\text { Presence }\end{array}$ & 66 & 1,00 & , 00 & 1,00 & 44,00 & ,6667 & ,05847 & 47502 & ,226 &,- 724 & ,295 & $-1,523$ & ,582 \\
\hline $\begin{array}{l}\text { Authorization } \\
\text { Certificate } \\
\text { Type }\end{array}$ & 66 & 2,00 & 1,00 & 3,00 & 182,00 & 2,7576 &, 06130 & ,49801 &, 248 & $-1,970$ & ,295 & 3,225 & ,582 \\
\hline $\begin{array}{l}\text { Location of } \\
\text { the firm }\end{array}$ & 66 & 1,00 & 1,00 & 2,00 & 90,00 & 1,3636 & ,05967 & ,48473 & 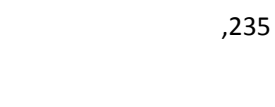 & ,580 & ,295 & $-1,716$ & ,582 \\
\hline $\begin{array}{l}\text { Income from } \\
\text { forex } \\
\text { operations in } \\
\text { TL }\end{array}$ & 66 & 71878112,00 & , 00 & 71878112,00 & 409322188,00 & 6201851,3333 & 1597933,68946 & 12981674,66125 & 168523877010555,250 & 3,527 & ,295 & 13,732 & ,582 \\
\hline $\begin{array}{l}\text { Number of } \\
\text { client } \\
\text { complaints } \\
\text { Valid N } \\
\text { (listwise) }\end{array}$ & $\begin{array}{l}66 \\
66\end{array}$ & 20,00 & , 00 & 20,00 & 156,00 & 2,3636 & ,53834 & 4,37347 & 19,127 & 2,559 & ,295 & 6,785 & ,582 \\
\hline
\end{tabular}


Group Statistics

\begin{tabular}{|c|c|c|c|c|c|}
\hline & Social Media Presence & $\mathrm{N}$ & Mean & Std. Deviation & $\begin{array}{c}\text { Std. Error } \\
\text { Mean }\end{array}$ \\
\hline \multirow{2}{*}{ Authorization Certificate Type } & No presence & 22 & 2,3636 & ,65795 & 14028 \\
\hline & Presence & 44 & 2,9545 & 21071 & 03177 \\
\hline \multirow{3}{*}{ Location of the firm } & No presence & 22 & 1,4545 &, 50965 & ,10866 \\
\hline & Presence & 44 & 1,3182 & ,47116 & 07103 \\
\hline & No presence & 22 & 1738344,3636 & 6025581,73950 & 1284658,34332 \\
\hline Income from forex operations in TL & Presence & 44 & 8433604,8182 & $\begin{array}{r}14890402,8300 \\
2\end{array}$ & 2244812,68929 \\
\hline \multirow{2}{*}{ Number of client complaints } & No presence & 22 & ,4545 & 1,92050 & ,40945 \\
\hline & Presence & 44 & 3,3182 & 4,93103 & ,74338 \\
\hline
\end{tabular}


Independent Samples Test

\begin{tabular}{|c|c|c|c|c|c|c|c|c|c|c|}
\hline & & \multicolumn{2}{|c|}{$\begin{array}{c}\text { Levene's Test for } \\
\text { Equality of } \\
\text { Variances } \\
\end{array}$} & \multicolumn{7}{|c|}{ t-test for Equality of Means } \\
\hline & & \multirow[t]{2}{*}{$\mathrm{F}$} & \multirow[t]{2}{*}{ Sig. } & \multirow[t]{2}{*}{$\mathrm{t}$} & \multirow[t]{2}{*}{ df } & \multirow{2}{*}{$\begin{array}{c}\text { Sig. } \\
(2- \\
\text { tailed })\end{array}$} & \multirow[t]{2}{*}{$\begin{array}{c}\text { Mean } \\
\text { Difference }\end{array}$} & \multirow[t]{2}{*}{$\begin{array}{l}\text { Std. Error } \\
\text { Difference }\end{array}$} & \multicolumn{2}{|c|}{$\begin{array}{l}\text { 95\% Confidence Interval of the } \\
\text { Difference }\end{array}$} \\
\hline & & & & & & & & & Lower & Upper \\
\hline \multirow{4}{*}{$\begin{array}{l}\text { Authorization Certificate } \\
\text { Type }\end{array}$} & Equal variances & 68,659 &, 000 & & 64 & ,000 &,- 59091 & , 10825 &,- 80717 &,- 37465 \\
\hline & assumed & & & 5,459 & & & & & & \\
\hline & $\begin{array}{l}\text { Equal variances not } \\
\text { assumed }\end{array}$ & & & 4,108 & 23,179 & ,000 &,- 59091 & , 14383 &,- 88831 &,- 29351 \\
\hline & $\begin{array}{l}\text { Equal variances } \\
\text { assumed }\end{array}$ & 2,759 &, 102 & 1,079 & 64 & ,285 &, 13636 &, 12641 &,- 11617 & 38890 \\
\hline \multirow{2}{*}{ Location of the firm } & $\begin{array}{l}\text { Equal variances not } \\
\text { assumed }\end{array}$ & & & 1,050 & 39,279 & 300 &, 13636 & ,12981 &,- 12615 & ,39888 \\
\hline & Equal variances & 4,768 &, 033 & & 64 & 047 & & 3312006,25955 & & $-78767,33456$ \\
\hline Income from forex & assumed & & & 2,022 & & & 6695260,45455 & & 13311753,57454 & \\
\hline \multirow[t]{3}{*}{ operations in TL } & Equal variances not & & & & 62,132 &, 012 & & 2586412,78010 & & \\
\hline & assumed & & & 2,589 & & & 6695260,45455 & & 11865207,88031 & 1525313,02878 \\
\hline & Equal variances & 10,832 &, 002 & & 64 &, 011 & $-2,86364$ & 1,09379 & $-5,04873$ &,- 67854 \\
\hline Number of client & assumed & & & 2,618 & & & & & & \\
\hline complaints & $\begin{array}{l}\text { Equal variances not } \\
\text { assumed }\end{array}$ & & & $\begin{array}{r}- \\
3,374\end{array}$ & 61,465 & 001 & $-2,86364$ & ,84868 & $-4,56043$ & $-1,16685$ \\
\hline
\end{tabular}




\begin{tabular}{|c|c|c|c|c|c|c|}
\hline \multicolumn{7}{|c|}{ Correlations } \\
\hline & & $\begin{array}{l}\text { Social Media } \\
\text { Presence }\end{array}$ & $\begin{array}{c}\text { Authorization } \\
\text { Certificate Type }\end{array}$ & $\begin{array}{l}\text { Location of the } \\
\text { firm }\end{array}$ & $\begin{array}{l}\text { Income from } \\
\text { forex operations } \\
\text { in } \mathrm{TL}\end{array}$ & $\begin{array}{l}\text { Number of client } \\
\text { complaints }\end{array}$ \\
\hline \multirow{4}{*}{ Social Media Presence } & Pearson Correlation & 1 &, $564^{* *}$ &,- 134 & $245^{*}$ & $311^{*}$ \\
\hline & Sig. (2-tailed) & &, 000 & ,285 &, 047 & 011 \\
\hline & $\mathrm{N}$ & 66 & 66 & 66 & 66 & 66 \\
\hline & Pearson Correlation &, $564^{* *}$ & 1 &,- 075 & ,232 & $246^{*}$ \\
\hline \multirow[t]{3}{*}{ Authorization Certificate Type } & Sig. (2-tailed) &, 000 & &, 548 & 061 & 047 \\
\hline & $\mathrm{N}$ & 66 & 66 & 66 & 66 & 66 \\
\hline & Pearson Correlation &,- 134 &,- 075 & 1 &,- 160 &,- 034 \\
\hline \multirow[t]{3}{*}{ Location of the firm } & Sig. (2-tailed) & ,285 &, 548 & & ,199 & ,785 \\
\hline & $\mathrm{N}$ & 66 & 66 & 66 & 66 & 66 \\
\hline & Pearson Correlation & $245^{*}$ & ,232 &,- 160 & 1 &, $346^{* *}$ \\
\hline \multirow[t]{3}{*}{ Income from forex operations in $T L$} & Sig. (2-tailed) &, 047 &, 061 & , 199 & & 004 \\
\hline & $\mathrm{N}$ & 66 & 66 & 66 & 66 & 66 \\
\hline & Pearson Correlation &, $311^{*}$ & ,246* &,- 034 &, $346^{* *}$ & 1 \\
\hline \multirow[t]{2}{*}{ Number of client complaints } & Sig. (2-tailed) & ,011 &, 047 & ,785 &, 004 & \\
\hline & $\mathrm{N}$ & 66 & 66 & 66 & 66 & 66 \\
\hline
\end{tabular}

**. Correlation is significant at the 0.01 level (2-tailed).

*. Correlation is significant at the 0.05 level (2-tailed).

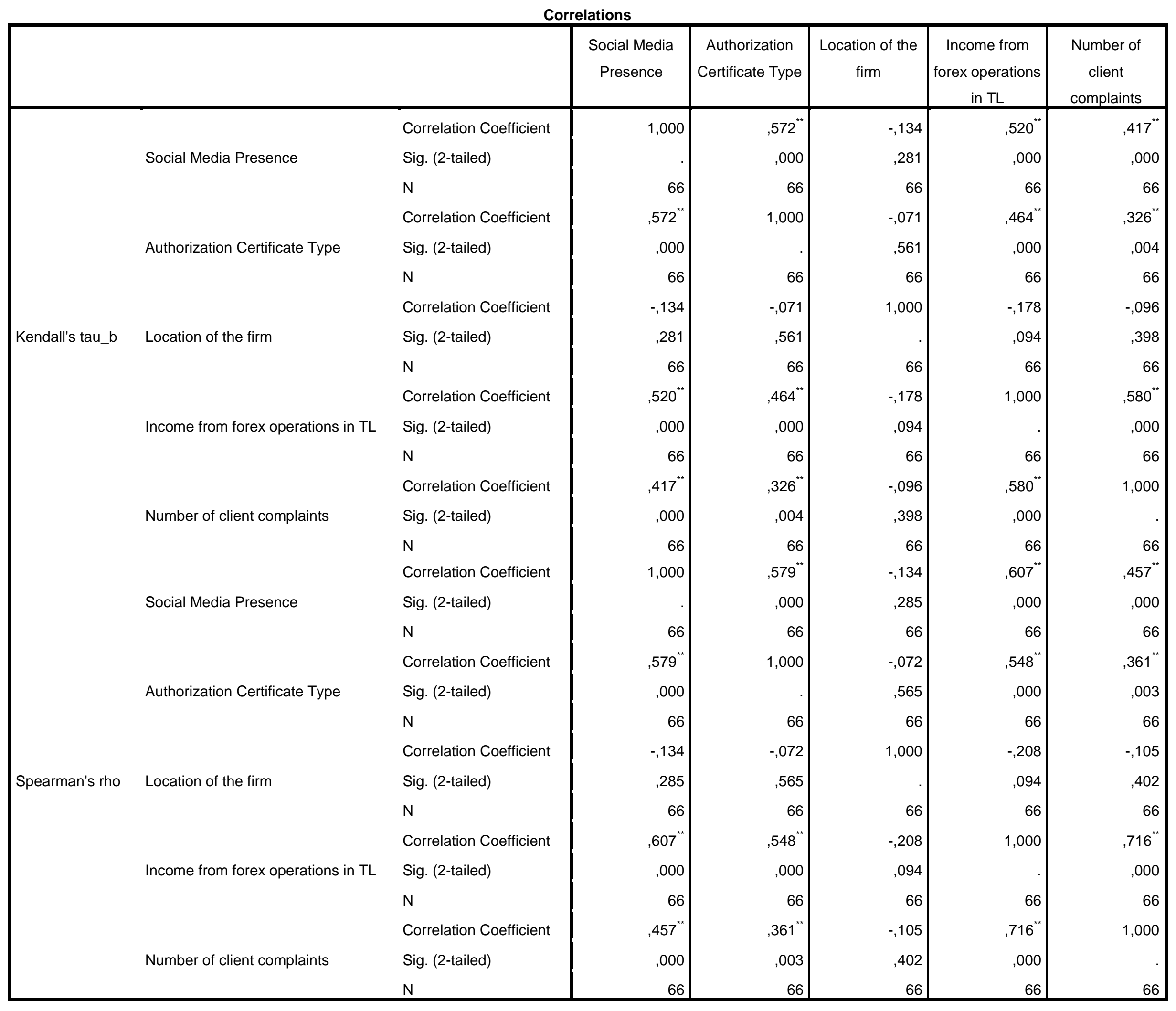

**. Correlation is significant at the 0.01 level (2-tailed). 